\title{
THE CRIMINAL OFFENCE OF "ABUSE" ON THE FAMILY INCLUDED IN THE BILL OF THE PENALTY CODE OF 6 JUNE 1997 IN THE ARTICLE 207 OF THE PENALTY CODE
}

\begin{abstract}
The subject of this article was to present the meaning of the word "abusive", which was presented in the Penal Code. The meaning of the word family and the premises it should fulfill in order to function properly were described. The article shows the premises that should be met in order to bring the perpetrator to criminal responsibility. The problem of the multiplicity of deed that is fulfilled by art. 207 of the Penal Code was presented, and the articles of the Penal Code, which enter as one act described in art. 207 of the Penal Code. It was also discussed why art. 207 of the Penal Code is subject to a more severe penalty than articles cumulated in art. 207 pp. A criminal threat is presented for an offense under art. 207 of the Penal Code and the qualified type of this article is raised in paragraph 3 and in paragraph 2, the content of the meaning of the word "with particular cruelty" is discussed.

It was described why the offense of abuse in the case of being committed against the loved ones is treated as one act and not attributed to the act separately to any person injured in the family. It was shown to whom the assessment of such action should be made. Common and individual crime, which occurs in art. 207 pp. It was demonstrated why art. 207 of the Penal Code and whose property it protects. Several judgments and judgments of the Courts of Appeals of the Supreme Courts were used, and the Judgment of the European Court of Human Rights was also referred to and the Convention on Human Rights was invoked.
\end{abstract}

Keywords: penal code from 1997, bullying, common offense, individual offense, family.

\section{INTRODUCTION}

Starting with the family and the crimes committed against the family, it is necessary to begin with its general concept, namely that in order the family could fully fulfill its assumptions, it must fulfill its function completely without any disruption. Speaking of disturbances, we are talking about deeds punishable against the welfare of the family, especially of its underage members. The family is the basic social unit where the most important value systems are transmitted. When these value systems are preserved, the sense of acceptance and love values work well and the development of the family and its youngest members (children) proceeds correctly, and thus adults who can ensure their proper development in a normal home atmosphere. At the moment when family values are disturbed, one can speak

\footnotetext{
${ }^{1}$ Przemysław Hus, MSc, District Prosecutor's Office in Rzeszów, ul. Lisa-Kuli 20, e-mail: przemyslaw.hus@wp.pl.

Mgr Przemysław Hus, Prokuratura Rejonowa w Rzeszowie, ul. Lisa-Kuli 20, e-mail: przemyslaw.hus@wp.pl.
} 
about the worst factor affecting this, i.e. family violence. Widely understood words of violence in the family, depending on the way of operation, scale and effects, may be characteristic of various crimes provided for in the penal code. Nevertheless, most often this behavior is classified as a crime of physical and mental abuse described in art. 207 of the Penal Code. The offense was included in chapter XXXVI concerning crimes against the family and the protection of the penal code of June 6, 1997 under article 207 of the Penal Code and was given the wording $\S 1$. Anyone who is physically or mentally harassed over the closest person or over another person who is in a permanent or temporary relationship of dependence on the offender is liable to imprisonment from 3 months to 5 years. Anyone who is physically or mentally harassed over a person who is clumsy due to their age, psychological or physical condition, is punished by imprisonment from 6 months to $8 \S 2$. If the act specified in $\S 1$ or $1 \mathrm{a}$ is combined with the use of special cruelty, the perpetrator is subject to punishment of imprisonment from one year to ten years, $\S 3$. If the act referred to in $\S 1-2$ is a bargaining of the aggrieved party to his own life, the perpetrator is punished by imprisonment from 2 to $12^{2}$.

\section{THE ANALYSIS OF PROVISIONS OF THE ACT}

Before the analysis of the offense under Art. 207 of the Penal Code it should be shown that for the existence of this crime it is necessary that the perpetrator has a total advantage over the victims, i.e. that this advantage could not be repelled by the victim in an effective manner or is repulsed to a limited extent. This means that the perpetrator with his behavior wants to give the closest person physical or mental pain to completely subordinate this person $^{3}$. The crime of abuse can be counted as individual or general offenses. An individual crime is said when the perpetrator commits this act to the closest person, i.e. a husband, wife, cohabitant or concubine, mother, father or persons in a permanent or temporary relationship of dependence on the offender. Transient relation of dependence, that is, the connection of people connected with a material, health or even only a psychological situation dependent on the perpetrator. This addiction may exist by law, for example, establishment of care, placement in a foster family ${ }^{4}$.

In the case of a common crime we mean the situation when the perpetrator ${ }^{5}$ mentally or physically abused a minor or somehow clumsy (clumsy people, i.e. persons who, due to old age, disability, bedridden illness or mental properties) (e.g. mental retardation) cannot decide their fate and change their position, then we talk about common offense. The exact definition of the closest person is contained in art. $115 \S 1$ of the Penal Code ${ }^{6}$ in the light,

${ }^{2}$ Ustawa kodeks karny z 6 czerwca 1997 r., Problemy nauk prawnych, t. 2, red. K. Pajer, Monografia Wrocław 2017, wstęp, s. 9, rozdz. II, s. 27, 33 (Penal Code Act of 6 June 1997, Problems of Legal Sciences, Vol. 2, Collective work edited by K. Pajer, Monography Wrocław 2017, introduction page 9, chapter II, pp. 27 and 33).

${ }^{3}$ G. Wrona, Konflikt a przemoc zastosowanie art. 207 k.k. w przeciwdziałaniu przemocy $w$ rodzinie, Warszawa 2016 (praca doktorska).

${ }^{4}$ A. Marek, Komentarz do art. 207 kodeksu karnego stan prawny 2010.03.01/lex.prz.edu.pl/ lex/content.rpc?localNroPart $=0 \&$ nro $=587262458 \&$ wersja $=-1 \&$ dataOceny $=2018-09$ $30 \&$ tknDATA $=13 \% 2 \mathrm{C} 35 \% 2 \mathrm{C} 6 \% 2 \mathrm{C} 9 \% 2 \mathrm{C} 1537950841 \&$ class $=$ CONTENT \&loc $=4 \& \mathrm{hId}=1 \&$ base Href=http\%3A\%2F\%2Flex.prz.edu.pl\%2Flex\%2Findex.rpc\&print $=1$

5 Ibidem, p. 1.

${ }^{6}$ The Penal Code of June 6, 1997 (Article $115 \S 1$ of the Penal Code). 
whose closest person is the preliminary, descendant, siblings, affinities in the same line or degree, the person remaining in the adoption ratio and her spouse, as well as the person remaining in cohabitation. The previous jurisprudence also took the view that the closest person for the offender is a stepson relative to the stepmother.

Considering the meaning of paragraph 1 of art. 207 of the Penal Code, it should be stated that the verbal mark "abusive" appears to be the behavior of the perpetrator. This behavior consists in asking someone (physically or mentally) suffering, tormenting, tormenting, mending over someone. Combining these for concealment means the act or omission of the perpetrator, consisting in the deliberate task of physical pain or onerous moral suffering, repeated or one-off, but intense and stretched in time. Behavior of the perpetrator causing physical and mental pain can only be committed in a direct intention ${ }^{7}$. Physical bullying consists in inflicting suffering on the other person's body in various ways. It may take the form of hitting the perpetrator with fists or with an open hand, various objects, digging, twisting hands, biting, stewing, burning (iron, cigarette or other objects), pushing, tugging at the hair, wringing hands, binding hands or legs, throwing for a wall or floor, forcing people to perform humiliating activities, spitting, throwing them out of the house, disturbing the silence and quiet at night, closing in dark rooms, throwing out of the house during the winter season without proper clothing, restricting access to food.

Psychological bullying consists in causing suffering to the victim's psyche, manifesting itself through insulting, humiliating, mocking, scaring, calling off, causing no domestic adventures, emotional rejection, being cut off from finances, refusing to go home, refusing to meet basic needs.

The above-mentioned behaviors of physical and psychological abuse fall into the category of multifocal crimes with collective enforcement activities. Its characteristic feature is the repeatability of the perpetrator's violation of the property protected by law. Bullying usually means a systematic repetition of behavior consisting of single or multi-generic individual activities that violate various goods ${ }^{8}$.

This means that for the assignment of the perpetrator of an act from art. 207 of the Penal Code is not required to satisfy all the above-mentioned conditions, i.e. physical and mental abuse, and it is enough for one of these conditions to be met.

In practice, the perpetrators are accused of perpetrating physical or mental abuse or both. Of course, in the case of physical abuse, as a rule, we also talk about psychological abuse because they are mostly combined factors. In contrast, in the case of mental abuse, there is not always a physical factor. While continuing further considerations, the attention should be paid to the problem frequently raised in case-law that in the case of art. 207 of the Penal Code we deal with a multitude of acts against one or several people at the same time. The essence of multifocal (collective) crime is based on multiplicity and repeatability of behavior. Therefore, it should be assumed that the behaviors that are included in the scope of abuse may therefore be marked by acts specified in other provisions, including art. 189, art.

\footnotetext{
7 Judgment of June 25, 2014, Court of Appeal - II AKa 160/14 http://lex.prz.edu.pl/lex/ content.rpc?nro $=118929717$ wersja $=-1$ dataOceny $=2018-09-30$ tknDATA $=13 \% 2 \mathrm{C} 35 \% 2 \mathrm{C} 6 \% 2 \mathrm{C} 9 \%$ 2C1537950841cla

8 A. Muszyńska, Commentary to art. 207 \& 1 of the Penal Code, legal status $2014.03 .01 \mathrm{http} / / / \mathrm{lex}$. prz.edu.pl/lex/content.rpc?localNroPart $=0 \& n r o=587370913 \&$ wersja $=-1 \&$ dataOceny $=2018-09$ $30 \& \mathrm{tknDATA}=13 \% 2 \mathrm{C} 35 \% 2 \mathrm{C} 6 \% 2 \mathrm{C} 9 \% 2 \mathrm{C} 1537950841 \& \mathrm{class}=\mathrm{CONTENT} \& \mathrm{loc}=4 \& \mathrm{hId}=1 \&$ base Href=http $\% 3 \mathrm{~A} \% 2 \mathrm{~F} \% 2$ Flex.prz.edu.pl\%2Flex\%2Findex.rpc\&print $=1$,
} 
190, art. 191, art. 216 and art. 217 p.p. Therefore, in the case of art. 207 of the Penal Code, we note that the sum of this type of behavior, defined as bullying, constitutes a slightly different type of offense (in Article 207 of the Penal Code a few of the above-mentioned offenses may be referred to) and apart from special cases only a certain sum of these crimes determines the depletion of the crime from art. $207 \S 1$ p.p.

In summary, it is concluded that, due to the well-protected nature of family functioning, it should be assumed that behavior violating the legal rights of more than one member of the family constitutes one offense of abuse referred to in art. $207 \S 1$ p.p., of course, in the situation of meeting other generally accepted criteria for the identity of an act. Hence, how rightly one can see the offense under art. 207 of the Penal Code is punishable by a stricter punishment than the individual unit acts mentioned in the offense mentioned above, and this is reflected in the prosecution procedure, which always occurs ex officio, and not from a private prosecution, therefore this article significantly helps to protect also personal rights victims even when they are unable to do it themselves. The article 207 p.p. is the basic instrument to combat the phenomenon of domestic violence. Therefore, it must be stated that because of the well-protected nature of the family's functioning, it is assumed that acts infringing the legal rights of more than one member of the family constitute one offense of abuse, of course, after meeting the accepted criteria of the identity of the act.

Also in the views of doctrine for the main good protected in art. 207 p.p. the family is universally recognized and functioning properly 9 .

The previous considerations concerned the first paragraph and paragraph 1a, but it is impossible not to take a position regarding paragraphs 2 and 3 of Art. 207 and so of the qualified type. The second paragraph speaks of the special cruelty of the act described in the first paragraph. Special cruelty has not been defined in the Penal Code, therefore the assessment whether the act of art. $207 \S 2$ has been fully implemented in each case is subject to review by the court and is examined in the course of court proceedings.

The case law assumes that it is inflicting suffering exceeding the intensity of "ordinary" abuse (specified in Article $207 \S 1$ of the Penal Code) and that particular cruelty in the behavior of the perpetrator should be associated not so much with the effects of the act, but primarily with the type and manner of action; should be analyzed in relation to a particular person, relatively to his physical and mental state ${ }^{10}$.

To sum up, particular cruelty should be considered individually for each perpetrator, taking into account the type and manner of its operation.

Turning to paragraph 3 of art. 207 of the Penal Code, the Supreme Court's judgment of 5 March $2014^{11}$ should be recalled, the title of which was to establish the intention of a victim of crime under Art. $207 \S 3$ of the Penal Code.

\footnotetext{
9 Decision of the Supreme Court of March 31, 2015 I KZP 1/2015 http://lex.prz.edu.pl/lex/ content.rpc?nro $=119151462 \&$ wersja $=-1 \&$ dataOceny $=2018-09-30 \&$ tknDATA $=$ $13 \% 2 \mathrm{C} 35 \% 2 \mathrm{C} 6 \% 2 \mathrm{C} 9 \% 2 \mathrm{C} 1537950841 \&$ class $=\mathrm{CONTENT} \& \mathrm{loc}=4 \& \mathrm{hId}=1 \&$ baseHref $=\mathrm{http} \% 3 \mathrm{~A}$ $\% 2$ F\%2Flex.prz.edu.pl\%2Flex \%2Findex.rpc\&print $=1$

10 Judgment of the Supreme Court of December 17, 1970, IV KR 199/70, OSNKW 1971, No. 5, item 7).

${ }^{11}$ Decision of the Supreme Court of 5 March 2014 IV KK316/13http://lex.prz.edu.pl/lex/ content.rpc?nro $=118907095 \&$ wersja $=-1 \&$ dataOceny $=2018-09-30 \&$ tknDATA $=$ $13 \% 2 \mathrm{C} 35 \% 2 \mathrm{C} 6 \% 2 \mathrm{C} 9 \% 2 \mathrm{C} 1537950841 \&$ class $=$ CONTENT $\&$ loc $=4 \& \mathrm{hId}=1 \&$ baseHref $=$ http\%3A\%2F\%2Flex.prz.edu.p1\%2Flex\%2Findex.rpc\&print=1
} 
In considering this, the court described the suicide attempt as a critical and final consequence of the perpetrator's act, preceded by the final and specific psychological attitude of the victim himself. Specified in paragraph 3 of art. 207 of the Penal Code, the concept of "slay" means, according to Polish literature, the occurrence of aggression against someone or something, abduction on someone, on something, should be seen only in the perspective of directional psychological attitude ${ }^{12}$. In other words, it is not necessary to state that the aggrieved party wanted to take his own life for the occurrence of the "hacking of the aggrieved party for his own life". It is sufficient to assume that at a critical moment there was an intention referred to as the resultant, namely: the victim, being aware that the final action (or omission) that he has taken may result in death (intellectual side), accepts this effect, i.e. he agrees your death (voluntary party). This acceptance of his death does not constitute a deliberate act or presumption by the aggrieved party that it may come and it is one of the consequences that arose in the victim's psyche. Quote, such an intention may take the form of an emergency (when the decision to commit suicide is made under the influence of emotions) or thoughtful (when this decision is preceded by considering the pros and cons). The adoption of a more restrictive concept, assuming that only the desire or willingness of one's own death entitles to treating a given behavior as a "bumping" on their own life, which is a necessary condition for attributing the perpetrator to abuse the stricter type qualified under art. $207 \S 3$ p.p., it would be too far-reaching. The point is that personal safety, health, and especially the lives of those who are dependent on the perpetrator would not be sufficiently protected by law. Summing up: the suicide decision of the aggrieved party, which is expressed by bumping his own life as a consequence of abuse (Article $207 \S 3$ of the penal code), at least means being aware of the possibility of taking his life as a result of specific behavior and accepting his own death ${ }^{13}$.

To summarize the above considerations, reference should be made not only to Polish court judgments, but also to European judgments, such as the Judgment of the European Court of Human Rights of 28 January 2014 26608/11 which in its title had a legal issue prohibiting inhuman and degrading treatment. Counteracting domestic violence. Illegal treatment must reach a minimum level of discomfort if it is to fall within the scope of application of Article 3 Convention (J.O.L.1993.61.284 - Convention for the Protection of Human Rights and Fundamental Freedoms made in Rome on November 4, 1950, subsequently amended by Protocols No. 3, 5 and 8 and supplemented by Protocol No. 2 . The assessment of this minimum is relative: it depends on all the circumstances of the case such as the nature and context of the treatment, the duration, its physical and mental effects and, in some cases, the sex, age and health of the victim.

\section{CONCLUSION}

To sum up, it should be noted that art. 207 of the Penal Code was created and introduced to the penal code in order to protect the family, including its minor members, and also to protect the clumsy and addicted people in a different way from the perpetrator of the abuse offense. This article is a guarantee for victims who, with the help of the State, can protect their rights and proper functioning in the family. The adopted solutions are in line with international standards.

\footnotetext{
${ }^{12}$ S. Dubisz, Uniwersalny stownik języka polskiego, Vol. IV, Warszawa 2003, p. 773.

${ }^{13}$ Ibidem, p. 10.
} 


\section{REFERENCES}

1. Dubisz S., Uniwersalny stownik języka polskiego, t. IV, Warszawa 2003, s. 773.

2. Wrona G., Konflikt a przemoc zastosowanie art. 207 k.k. w przeciwdziałaniu przemocy $w$ rodzinie, Warszawa 2016 (praca doktorska).

3. Ustawa kodeks karny z dnia 6 czerwca 1997 r., Problemy nauk prawnych, t. 2, red. K. Pajer, Monografia Wrocław 2017, wstęp, s. 9, rozdz. II, s. 27, 33.

\section{LEGAL ACTS}

1. Ustawa z dnia 6 czerwca 1997 r. - Kodeks karny (tekst jedn. Dz.U. z 2018 r., poz. 1600).

\section{JUDICAL DECISIONS}

1. Wyrok Sądu Najwyższego z dnia 17 grudnia 1970 r., IV KR 199/70, OSNKW 1971, nr 5, poz. 7).

2. Wyrok z dnia 25 czerwca 2014 r., Sąd Apelacyjny - II AKa 160/14 http://lex.prz.edu.pl/lex/ content.rpc?nro=118929717 wersja=-1 dataOceny=2018-09-30tknDATA= 13\%2C35\%2C6\%2C9\%2C1537950841cla.

3. Postanowienie Sadu Najwyższego z dnia 31 marca 2015 r., I KZP 1/2015 http://lex.prz.edu. $\mathrm{pl} /$ lex/content.rpc?nro=119151462\&wersja $=-1 \&$ dataOceny $=2018-09-30 \&$ tknDATA $=$ $13 \% 2 \mathrm{C} 35 \% 2 \mathrm{C} 6 \% 2 \mathrm{C} 9 \% 2 \mathrm{C} 1537950841 \&$ class $=$ CONTENT $\&$ loc $=4 \& \mathrm{hId}=1 \&$ baseHref $=$ http\%3A\%2F\%2Flex.prz.edu.p1\%2Flex\%2Findex.rpc\&print=1.

4. Postanowienie Sądu Najwyższego z dnia 5 marca 2014 r., IV KK316/13http://lex.prz.edu.pl/ lex/content.rpc?nro $=118907095 \&$ wersja $=-1 \&$ dataOceny=2018-09-30\&tknDATA= $13 \% 2 \mathrm{C} 35 \% 2 \mathrm{C} 6 \% 2 \mathrm{C} 9 \% 2 \mathrm{C} 1537950841 \&$ class $=\mathrm{CONTENT} \& \mathrm{loc}=4 \& \mathrm{hId}=1 \&$ baseHref $=$ http\%3A\%2F\%2Flex.prz.edu.pl\%2Flex\%2Findex.rpc\&print=1.

\section{INTERNET SOURCES}

1. Marek A., Komentarz do art. 207 kodeksu karnego, stan prawny 2010.03.01/lex.prz.edu.pl/lex/content.rpc?localNroPart=0\&nro=587262458\&wersja=$1 \&$ dataOceny $=2018-09$ 30\&tknDATA $=13 \% 2 \mathrm{C} 35 \% 2 \mathrm{C} 6 \% 2 \mathrm{C} 9 \% 2 \mathrm{C} 1537950841 \&$ class $=\mathrm{CONTENT} \& \mathrm{loc}=4 \& \mathrm{hId}=1$ \&baseHref=http\%3A\%2F\%2Flex.prz.edu.pl\%2Flex\%2Findex.rpc\&print=1.

2. Muszyńska A., Komentarz do art. 207 \& $1 \mathrm{kk}$, stan prawny 2014.03.01http://lex.prz.edu.pl/lex/content.rpc?localNroPart=0\&nro=587370913\&wersja=$1 \&$ dataOceny $=2018-09$ $30 \&$ tknDATA $=13 \% 2 \mathrm{C} 35 \% 2 \mathrm{C} 6 \% 2 \mathrm{C} 9 \% 2 \mathrm{C} 1537950841 \& \mathrm{class}=\mathrm{CONTENT} \& \mathrm{loc}=4 \& \mathrm{hId}=1$ \&baseHref=http\%3A\%2F\%2Flex.prz.edu.pl\%2Flex\%2Findex.rpc\&print=1. 


\section{PRZESTEPSTWO „ZNECCANIA SIE”” NAD RODZINĄ ZAWARTE W USTAWIE KODEKS KARNY Z DNIA 6 CZERWCA 1997 R. POD ART. 207 KODEKSU KARNEGO}

Przedmiotem niniejszego artykułu było przedstawienie znaczenia słów ,znęca się”, które zostało przedstawione w ustawie kodeks karny. Opisano znaczenie słowa ,rodzina” oraz przesłanki, jakie powinna ona spełniać, aby prawidłowo mogła funkcjonować. W artykule wykazano przesłanki, jakie winny być spełnione, aby pociągnąc sprawcę do odpowiedzialności karnej. Poruszono także problem wielości czynu, które wypełnia art. 207 k.k. oraz wymieniono artykuły kodeksu karnego, które wchodzą jako jeden czyn opisany w art. 207 k.k., a także przedstawiono, dlaczego art. 207 k.k. jest zagrożony karą surowszą od artykułów skumulowanych w art. 207 k.k. Przedstawiono zagrożenie karne za przestępstwo z art. 207 k.k. oraz poruszono typ kwalifikowany tego artykułu umieszczony w $\S 3$ oraz w $\S 2$ omówiono treść znaczenia słów ,ze szczególnym okrucieństwem”.

Opisano, dlaczego przestępstwo znęcania w przypadku, gdy zostaje popełnione wobec osób najbliższych traktowane jest jako jeden czyn, a nie przypisuje się tego czynu osobno wobec każdej osoby pokrzywdzonej w rodzinie. Wykazano, do kogo należy ocena takiego działania. Porównano i opisano przestępstwo powszechne i indywidualne, które występuje w art. 207 k.k. Wykazano, czemu służy art. 207 k.k. i czyjego dobra chroni. Wykorzystano kilkanaście orzeczeń i wyroków Sądów Apelacyjnych Sądów Najwyższych, a także przytoczono Wyrok Europejskiego Trybunału Praw Człowieka oraz powołano się na Konwencję Praw Człowieka.

Słowa kluczowe: kodeks karny z 1997 r., znęcanie się, przestępstwo powszechne, przestępstwo indywidualne, rodzina.

DOI: $10.7862 / \mathrm{rz} .2018 . \mathrm{hss} .70$

Tekst złożono w redakcji: październik 2018 r.

Tekst przyjęto do druku: grudzień 2018 r. 
